\title{
Meloidogyne incognita: Molecular cloning and characterization of a cDNA encoding a cathepsin D-like aspartic proteinase
}

\author{
Rodrigo da Rocha Fragoso a,b,1, Isabela Tristan Lourenço b,1, João Aguiar Nogueira Batista ${ }^{c}$, Osmundo \\ Brilhante Oliveira-Neto ${ }^{d}$, Maria Cristina Mattar Silva ${ }^{d}$, Thales Lima Rocha ${ }^{d}$, Marise Ventura Coutinho ${ }^{d}$, \\ Maria Fátima Grossi-de-Sa d,* \\ a Embrapa, Cerrados, Planaltina, DF, Brazil

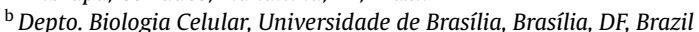 \\ ${ }^{\mathrm{c}}$ Depto. Botânica, Universidade Federal de Minas Gerais, Belo Horizonte, MG, Brazil \\ ${ }^{\mathrm{d}}$ Embrapa Recursos Genéticos e Biotecnologia, PqEB Final Av. W/5 Norte, CEP 70.770-900, Brasília, DF, Brazil
}

\section{A R T I C L E I N F O}

\section{Article history:}

Received 15 May 2007

Received in revised form 29 September

2008

Accepted 30 September 2008

Available online 7 October 2008

\section{Keywords:}

cDNA cloning

Meloidogyne

Nematode

Aspartic proteinase

Cathepsin D

RKM, root-knot nematode

$\mathrm{CN}$, cyst nematode

L2, second-stage larva or juvenile

AP, aspartic proteinase

RACE, rapid amplification of cDNA ends

EST, expressed sequence tag

RT-PCR, reverse transcription and polymer-

ase chain reaction

ORF, open read frame

\section{Introduction}

The endoparasitic sedentary nematodes of the genera Heterodera, Globodera (known as cyst nematodes, $\mathrm{CN}$ ) and Meloidogyne (the root-knot nematodes, RKN) are major crop phytopathogens, causing estimated losses of $\$ 125$ billion USD annually (Chitwood, 2003). The southern root-knot nematode, Meloidogyne incognita, is probably the most damaging plant pathogen in the scope of global agriculture (Trudgill and Blok, 2001), mainly due to its wide host range, worldwide distribution, apomictic reproduction and high reproductive rate.

These sedentary plant-parasitic nematodes share some parasitism mechanisms, which insure host-tissue invasion and hostdefense evasion (Davis et al., 2004). Parasitism establishment and

\footnotetext{
* Corresponding author.

E-mail address: fatimasa@cenargen.embrapa.br (M.F. Grossi-de-Sa).

1 These authors contributed equally to the work.
}

maintenance are based upon several secreted molecules that alter plant cellular programs, transforming them into enlarged, multinucleate, and metabolically active feeding cells called syncytia in $\mathrm{CN}$-infected plants or giant cells in RKN-infected plants (Gheysen and Fenoll, 2002).

Nematicides, crop rotation, bio-control agents, and/or host resistance have not been successfully deployed against nematodes, except in some rare cases (Bird and Kaloshian, 2003). Following the anti-feeding strategy based on inhibition of nematode digestive enzymes, plant transformation with genes encoding proteinase inhibitors represents a promising solution (Lilley et al., 1999a; Lilley et al., 1999b; Atkinson et al., 2001). Several reports described the characterization of proteinase activities in crude protein extracts of plant-parasitic nematodes (Lilley et al., 1996; Michaud et al., 1996) or the isolation of their proteinase genes (Lilley et al., 1997; Urwin et al., 1997a; Neveu et al., 2003; Fragoso et al., 2005). Several reports demonstrate inhibition of nema- 
tode proteinase inhibition in planta, in vivo or in vitro, respectively, upon use of proteinase inhibitor genes (Urwin et al., 1997b; Urwin et al., 1998; Atkinson et al., 2001), inhibition of proteinase gene expression by RNAi (Urwin et al., 2002) or inhibition of proteinase activity using a cognate pro-region of nematode proteinase (Silva et al., 2004). In all cases, the nematode digestive enzymes targeted were serine or cysteine proteinases, since previous studies had characterized their strong activity in the intestine of plant-parasitic nematodes (Lilley et al., 1996). Thus, little attention had been given to other proteinase classes in plant-parasitic nematode studies.

Aspartic (or aspartyl) proteinases (AP) are ubiquitously expressed and participate in several different functions, being a widely distributed protein superfamily (Coombs et al., 2001) that share high identity in amino acid sequences with one another (Wittlin et al., 1999). Animal-parasitic nematodes, trematodes, apicomplexans, fungus, and arachnids possess APs, which have major roles in their interaction with the host animal, and are normally associated with host skin penetration, tissue migration, immune response evasion, and hemoglobin digestion (Jean et al., 2001; Williamson et al., 2003a; Morales et al., 2004; Kalkanci et al., 2005). Aiming to affect plant nematode resistance by plant transformation with anti-parasitic elements and considering the major importance of APs in animal parasitism, we initiated a molecular approach to discover AP cDNAs in plant-parasitic nematodes. Herein we report the first cloning and characterization of an aspartic proteinase cDNA (Mi-asp1) from the southern root-knot nematode $M$. incognita.

\section{Materials and methods}

\subsection{Growth and collection of M. incognita}

Since $M$. incognita is an obligatory endoparasitic plant nematode, we cultivated it in a host plant, i.e. in tomato (Lycopersicon esculentum) inoculated roots. Nematodes were harvested at three different life stages (eggs, second-stage larvae L2 and adult females) by standard protocols (Hussey and Barker, 1973). Briefly, the tomato roots were washed and triturated to separate nematode eggs through a $32 \mu \mathrm{m}$ sieve. This fraction was cleaned by centrifugation in $50 \%(\mathrm{w} / \mathrm{v})$ sucrose and eggs were collected from the supernatant through a $32 \mu \mathrm{m}$ sieve. Pre-parasitic second-stage larvae (L2) were obtained from eggs hatched in vitro. Adult parasitic females were obtained from infected tomato roots incubated overnight in $40 \%(\mathrm{v} / \mathrm{v})$ pectinase followed by digestion of plant tissue and release of the female individuals therein. The tissue was then cleared via centrifugation in $40 \%(\mathrm{w} / \mathrm{v})$ sucrose in order to retain the females in the supernatant for collection in a $150 \mu \mathrm{m}$ sieve.

\subsection{Proteolytic assays}

The crude protein extracts of whole $M$. incognita females were prepared to evaluate the AP activity with a fluorimetric assay using the AP-specific substrate $N$-succinyl-Arg-Pro-Phe-HisLeu-Leu-Val-Try-MCA (4-methyl-7-coumaryl-amide) and the AP-specific inhibitor Pepstatin A. Substrate hydrolysis increases fluorescence, whereas the AP-specific inhibitor decreases it. Approximately $250 \mathrm{mg}$ of females were triturated in $250 \mu \mathrm{l}$ of acidic buffer $(0.1 \mathrm{M}$ sodium acetate and $0.5 \% \mathrm{v} / \mathrm{v}$ Triton-100; $\mathrm{pH}$ 4.8 ) at $4{ }^{\circ} \mathrm{C}$, centrifuged at $14,000 \mathrm{~g}$ for $15 \mathrm{~min}$ and the supernatant was used as a crude protein extract in the AP activity assays. The proteolytic reaction was carried out at $37^{\circ} \mathrm{C}$ for $30 \mathrm{~min}$ in a final volume of $100 \mu \mathrm{l}$ of acidic buffer with $10 \mu \mathrm{l}$ of crude protein extract, $10 \mu \mathrm{M}$ substrate, 5\% DMSO, $2.5 \mathrm{mM}$ DTT and, only in inhibited samples, $10 \mu \mathrm{M}$ inhibitor, pre-incubated with the protein extract at $37^{\circ} \mathrm{C}$ for $30 \mathrm{~min}$. The reactions were stopped with $1.9 \mathrm{ml}$ of $0.2 \mathrm{M} \mathrm{Na}_{2} \mathrm{CO}_{3}$. White proofs were made by adding protein extract after this last solution. The samples were quantified using a fluorescence reader (DyNA Quant 500, PharmaciaBiotech) with excitation and emission wavelengths of 365 and $460 \mathrm{~nm}$, respectively.

\subsection{RT-PCR amplification}

Total RNA from M. incognita L2 was extracted using an RNeasy kit (Qiagen) according to the manufacturer's protocol. Reverse transcription of total RNA $(2 \mu \mathrm{g})$ was performed with a d(T)-anchor primer and AMV-RT (Roche Applied Science), according to the manufacturer's instructions. PCR amplification was carried out using the degenerate primers ASP1 (sense, $5^{\prime}$-GGTTCWTCYAATCTBTGG$3^{\prime}$ ) and ASP2rev (antisense, 5'-CCMAGRATHCCRTCAAA-3'), designed based on conserved motifs flanking the catalytic aspartic residues of known AP sequences. The PCR system (final volume, $25 \mu \mathrm{l}$ ) contained $2.5 \mathrm{U}$ of Taq DNA polymerase (Invitrogen), $2.0 \mathrm{mM}$ $\mathrm{MgCl}_{2}, 200 \mu \mathrm{M}$ of dNTPs and $400 \mathrm{nM}$ of each primer. The PCR program consisted of an initial denaturation at $94^{\circ} \mathrm{C}$ for $1.5 \mathrm{~min}, 30$ cycles of amplification at $94^{\circ} \mathrm{C}$ for $30 \mathrm{~s}, 45^{\circ} \mathrm{C}$ for $45 \mathrm{~s}$ and $72^{\circ} \mathrm{C}$ for $1.5 \mathrm{~min}$, followed by a final elongation step at $72^{\circ} \mathrm{C}$ for $5 \mathrm{~min}$. An aliquot of the PCR product was then used for a second round of amplification at the same conditions.

\section{4. $5^{\prime}$ and $3^{\prime} R A C E$}

The $5^{\prime}$ end of the cDNA fragment derived by RT-PCR was amplified by 5' RACE using a 5'/3' RACE kit (Roche Applied Science) according to the manufacturer's instructions. The antisense primer Mi-asp4a (5'-GTTAGTCCTGGCTCGCTG-3') was used for reverse transcription and the antisense primers Mi-asp4b $\left(5^{\prime}-\mathrm{ACT}\right.$ CTTGCCAGCCACAC- $3^{\prime}$ ) and Miasp4c (5'-GTGATGGAGTAGGCATGC$3^{\prime}$ ) were used for the first and second round of a 5' RACE nested-PCR, respectively. The first-round $5^{\prime}$ RACE PCR conditions comprised a denaturation step at $94{ }^{\circ} \mathrm{C}$ for $1.5 \mathrm{~min}, 30$ cycles of $94{ }^{\circ} \mathrm{C}$ for $45 \mathrm{~s}$, $42^{\circ} \mathrm{C}$ for $45 \mathrm{~s}$, and $72{ }^{\circ} \mathrm{C}$ for $1.5 \mathrm{~min}$, and a final elongation step at $72^{\circ} \mathrm{C}$ for $5 \mathrm{~min}$. The same conditions were used for the second $5^{\prime}$ RACE PCR round, except that the annealing temperature was $52^{\circ} \mathrm{C}$. Contiguous sequences downstream of the $5^{\prime}$ RACE PCR product were amplified by 3' RACE after two rounds of a nested PCR with specific sense primers designed based on the $5^{\prime}$ RACE-obtained sequence, named Miasp4d (5'-CATCACCATGTCGATCG-3') and Miasp4e (5'-CCGAATGGATACAATGCG-3'). First-round 3' RACE PCR conditions were as follows: denaturation step at $94^{\circ} \mathrm{C}$ for $1.5 \mathrm{~min}$, 30 cycles of $94^{\circ} \mathrm{C}$ for $30 \mathrm{~s}, 55^{\circ} \mathrm{C}$ for $30 \mathrm{~s}, 72^{\circ} \mathrm{C}$ for $1.5 \mathrm{~min}$ and final elongation at $72^{\circ} \mathrm{C}$ for $5 \mathrm{~min}$. The second-round of the $3^{\prime} \mathrm{RACE}$ PCR was performed at the same conditions, but with 35 cycles of amplification.

\subsection{Southern blotting analysis}

Genomic DNA from $M$. incognita eggs ( $8 \mu \mathrm{g}$ each) was digested (with EcoRI, HindIII, XbaI, PstI or NsiI), electrophoresed on a $0.8 \%$ agarose gel and transferred to a Hybond $\mathrm{N}+$ nylon membrane (Amersham Pharmacia Biotech, UK) using standard procedures (Sambrook et al., 1989). The Mi-asp1 fragment of 1471-bp was labeled with $\alpha-\left[{ }^{32} \mathrm{P}\right] \mathrm{dCTP}$ to a high specific activity using the Megaprimer DNA-labeling kit (Amersham Pharmacia Biotech) and used to probe the blot. The membrane was washed with a stringency of $1 \times$ SSC with $0.2 \%$ SDS at $65^{\circ} \mathrm{C}$.

\subsection{Mi-asp1 gene expression analysis}

Total RNA from M. incognita eggs, larvae and females was purified using the RNAspin mini kit (G\&E) according to the manufac- 
turer's protocol. Reverse transcription reactions were performed simultaneously by incubation of $3 \mu \mathrm{g}$ of total RNA from each life stage in aliquots of the same reagents mix from the SuperScript ${ }^{\mathrm{TM}}$ kit (Invitrogen), according to the manufacturer's protocol. Subsequently, the five RT-PCR amplifications were done using aliquots of the same reagents mix, including the two pairs of specific primers for $\beta$-actin (ActFor 5'-GATCTGGCATCACACCTTCTAC-3' and ActRev 5'-AGGAAGCTCGTAGCTCTTCTC-3') and Mi-asp1 (Miasp4e and MiAspEnd 5'-GGGGGTACCGAGCAATTTCAATAAAATCATC$\left.3^{\prime}\right)$ genes together. For these PCR amplifications, each one of the three nematode-synthesized cDNAs was added as template $(1 \mu \mathrm{l})$ to a reaction mix $(24 \mu \mathrm{l})$ in separate microtubes. Negative and positive control reactions were performed using water or genomic DNA as the template, respectively. The PCR conditions consisted of a denaturation step at $92^{\circ} \mathrm{C}$ for $2 \mathrm{~min}, 30$ cycles at $92^{\circ} \mathrm{C}$ for $1 \mathrm{~min}, 55^{\circ} \mathrm{C}$ for $1 \mathrm{~min}$ and $72^{\circ} \mathrm{C}$ for $1.5 \mathrm{~min}$, and a final extension step at $72^{\circ} \mathrm{C}$ for $5 \mathrm{~min}$.

\subsection{Database searching and sequence retrieval for nematode aspartic proteinases}

The nucleotide sequence of Mi-asp1 was used as a query in BLAST searches within the Caenorhabiditis elegans genome at WormBase (http://www.wormbase.org) and within the plant-parasite nematode dbEST at the Nematode Center (http://www.nematode.net). A GenBank ${ }^{\mathrm{TM}}$ search at NCBI (http://www.ncbi.nlm.nih. gov) was also done using as a query combination of words that specify developmental stage and gene annotation after the Taxonomy ID of the RKN (189290).

\subsection{DNA sequencing and sequence analysis}

The amplified cDNA fragments were cloned into pGEM-T Easy (Promega) and sequenced in both strands using an automated ABI DNA sequencer. Comparisons of the cloned cDNA sequence with other GenBank ${ }^{\mathrm{TM}}$ database sequences were performed using BLASTx software (Altschul et al., 1990) from the NCBI site (http://www.ncbi.nlm.nih.gov). The CDD-Search soft-
Table 1

Proteolytic assays to detect aspartic proteinase activity in crude extract of $M$. incognita females.

\begin{tabular}{|c|c|c|c|c|c|c|c|c|}
\hline & & AP activity & White 1 & $\Delta 1$ & Inhibited & White 2 & $\Delta 2$ & \% Residual \\
\hline First & & 59 & 11 & & 48 & 29 & & \\
\hline \multirow[t]{2}{*}{ Extract } & & 55 & 3 & & 40 & 29 & & \\
\hline & Media & 57 & 7 & 50 & 44 & 29 & 15 & 30 \\
\hline Second & & 84 & 6 & & 47 & 17 & & \\
\hline \multirow[t]{2}{*}{ Extract } & & 97 & 5 & & 47 & 37 & & \\
\hline & Media & 90.5 & 5.5 & 85 & 47 & 27 & 20 & 24 \\
\hline
\end{tabular}

ware from the NCBI site was used to make a conserved domains determination (Marchler-Bauer et al., 2003). Signal peptide and cleavage-site identification was performed using SignalP software (Nielsen et al., 1997) of the Center for Biological Sequence Analysis (http://www.cbs.dtu.dk/services/SignalP/). Multiple sequence alignments were performed using CLUSTAL_W software (Thompson et al., 1994) and edited using BOXSHADE software (http://www.ch.embnet.org/software/BOX_form.html). Molecular mass values and isoelectric points were predicted using the deduced protein sequence by analysis with Compute $\mathrm{pI} / \mathrm{MW}$ tool software available at the Expasy website (http://ca.expasy.org/ tools/pi_tool.html).

\section{Results}

\subsection{Proteolytic assays}

As a first step to identifying potential targets for anti-feeding strategies, we initiated a search for AP activity. Proteolytic activity was detected in crude protein extracts of $M$. incognita females when using acidic buffer and AP-specific substrate (Table 1). This experiment, conducted in two technical replicates of two biological replicates, demonstrated a substantial decrease $(\sim 70 \%)$ in proteolytic activity when using the AP-specific inhibitor pepstatin A (Table 1).
A

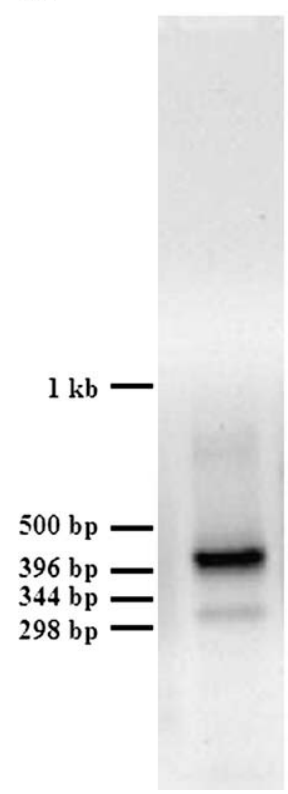

B

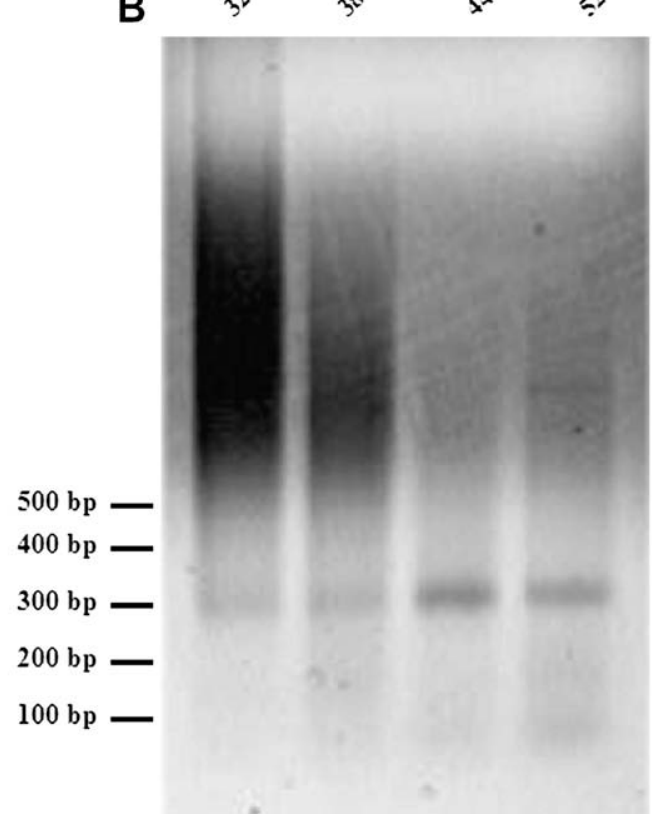

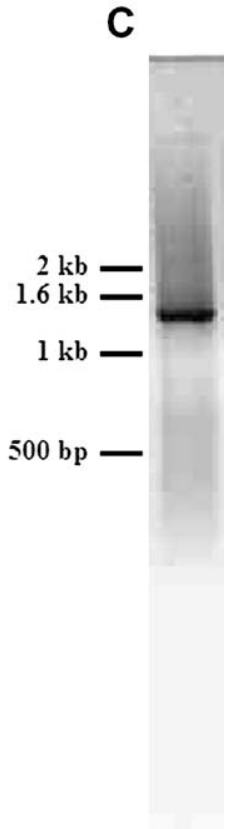

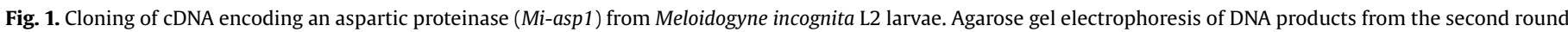
of amplifications: (A) 5' RACE PCR. (B) RT-PCR, using different annealing temperatures. (C) 3' RACE PCR. 


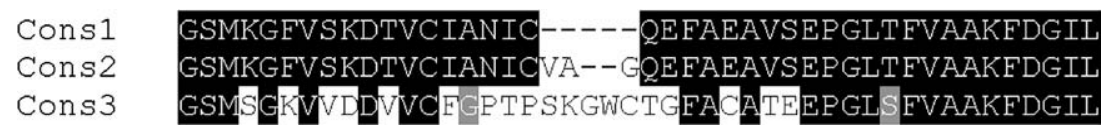

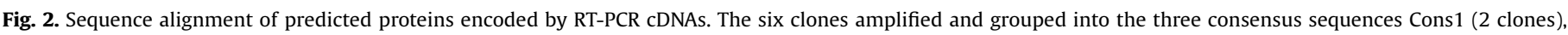

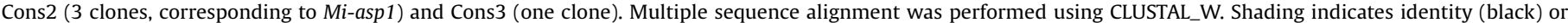
similarity (gray).

\subsection{Cloning and characterization of a cDNA encoding an aspartic proteinase}

RT-PCR amplification of total RNA from $M$. incognita L2 larvae was performed using degenerate primers designed to amplify AP conserved motifs (Beynon and Bond, 1994). These amplifications resulted in fragments of $300 \mathrm{bp}$ that, after sequencing, revealed six different cDNAs encoding putative APs (Fig. 1B). Multiple sequence alignment of these six cDNAs allowed them to be grouped into three consensus sequences of predicted amino acids (Fig. 2). Two consensus sequences had high amino acid sequence identity with each other and with AP sequences from Ancylostoma caninum (76\%) and Onchocerca volvulus (72\%), both of which were found in the GenBank ${ }^{\mathrm{TM}}$ databases. A third consensus sequence showed $60 \%$ and $56 \%$ identity with the first and second consensus sequences, respectively. Antisense primers were designed to amplify all three consensus sequences using 5' RACE, but only the second one was actually amplified. A 400-bp fragment, corresponding to a consensus sequence stretch of $M$. incognita AP, was isolated and sequenced, revealing an open reading frame (ORF) contiguous with the previous RT-PCR cDNA; however, it lacked a start codon in frame with the coding sequence (Fig. 1A). Through 3' RACE, using primers based on the sequence of the 5' RACE product, a 1471-bp fragment (Fig. 1C) contiguous with the previous was isolated and named Mi-asp1 (Fig. 3).
Southern blotting was performed to estimate the abundance of AP genes within the $M$. incognita genome. Samples of equal amounts of genomic DNA were digested with EcoRI, HindIII, XbaI and PstI, which do not cleave the Mi-asp1 cDNA, and NsiI, which cleaves it twice, and electrophoresed in agarose gel (Fig. 4A). We also amplified a fragment of Mi-asp1 gene using as template gDNA isolated from $M$. incognita eggs and primers MiaspPro and MiaspEnd (Fig. 3), which almost compass the complete extension of the labeled Mi-asp1 cDNA. PCR product was purified, digested and electrophoresed showing intron presence with restriction site to PstI endonuclease (data not shown).

Considering the EcoRI, HindIII, and XbaI DNA digestions first, which do not cut the labeled region of Mi-asp1 gene, the first three lines showed one darker signal, most likely corresponding to the Mi-asp1 gene, and other fainter signals (three, three and two, respectively) probably corresponding to other AP genes (Fig. 4B and $\mathrm{C}$ ).

On the other hand, the lines with Psil and Nsil DNA digestions, which cut the labeled region of Mi-asp1 gene, did not show one darker signal (Fig. 4B). Indeed, the PstI line showed three bands with similar darker signal, and three bands with fainter signals. The Nsil enzyme cleaves Mi-asp1 cDNA at 144 and 968 positions and generates an 824-bp fragment. Indeed, the last line showed two darker signals around $1 \mathrm{~kb}$, because inserted intron(s) adds

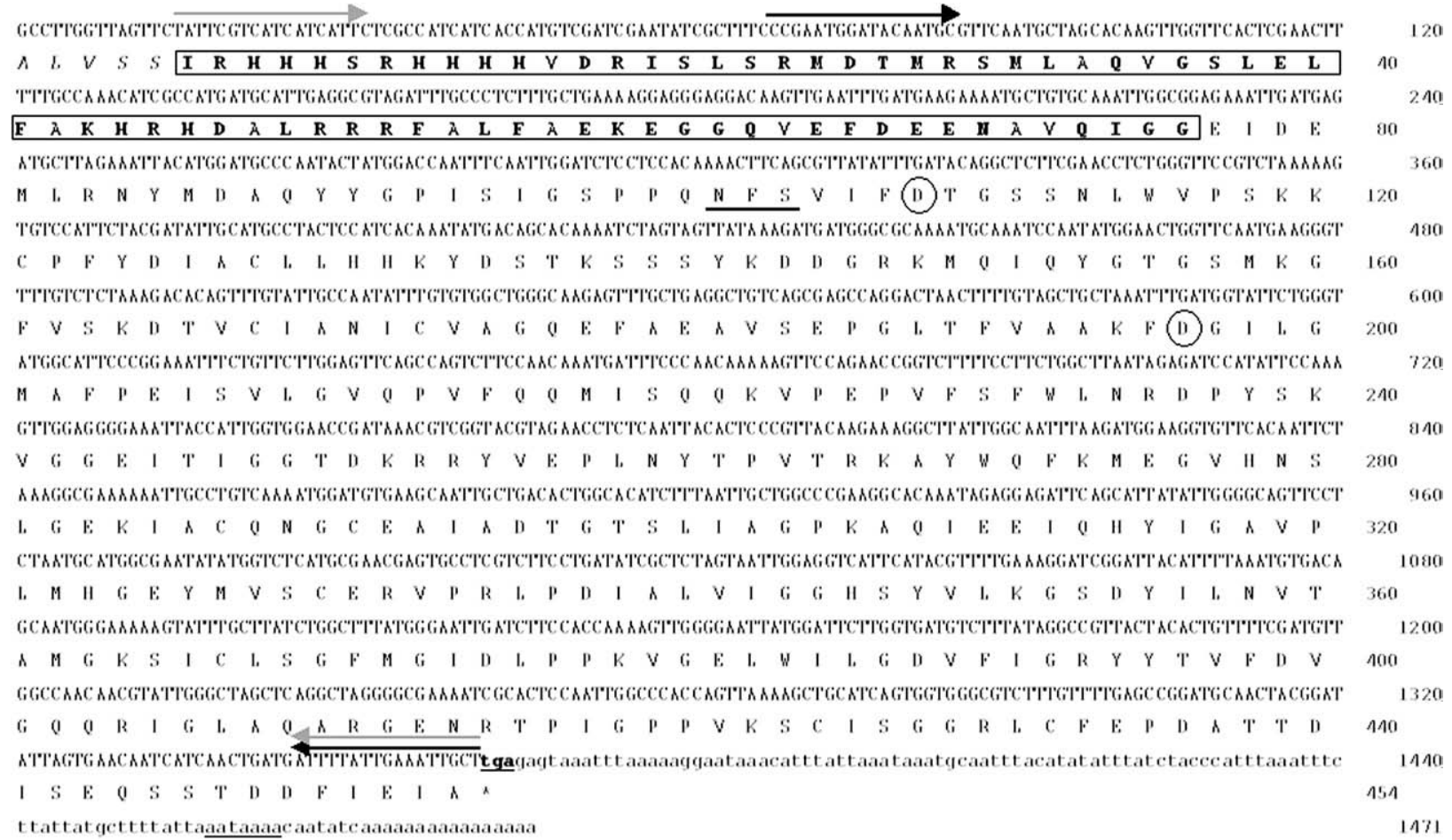

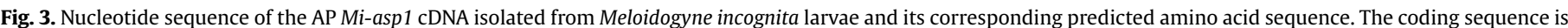

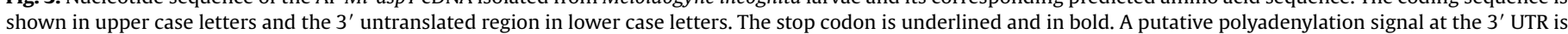

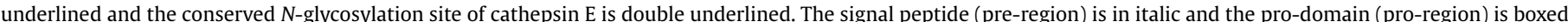

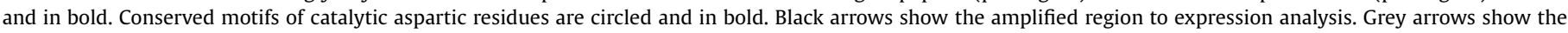

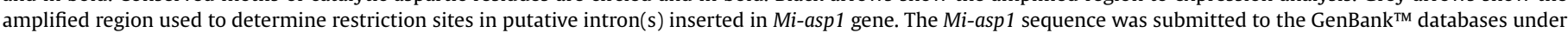
accession number DQ360827. 


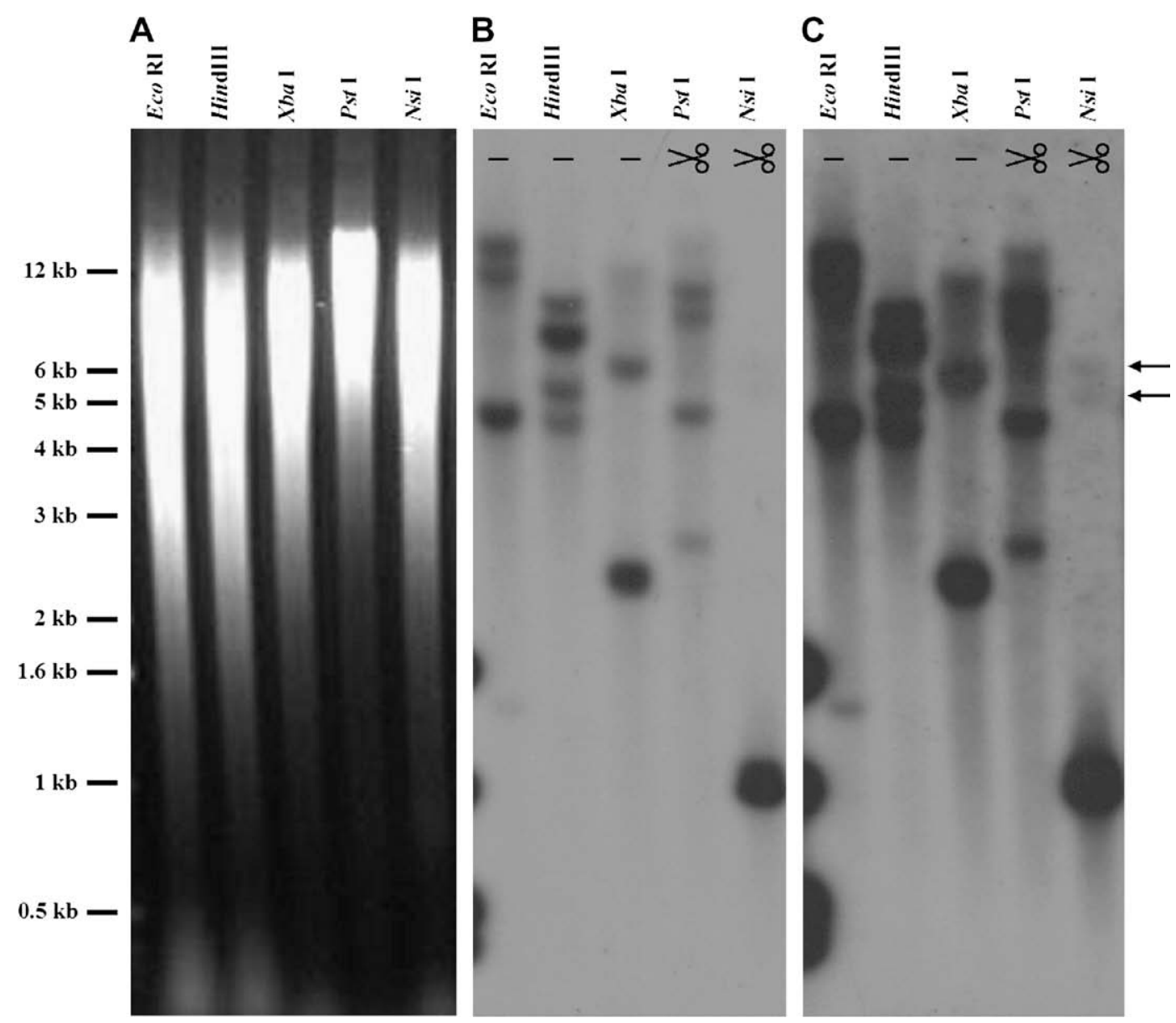

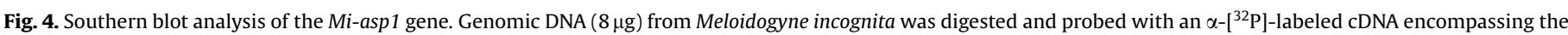

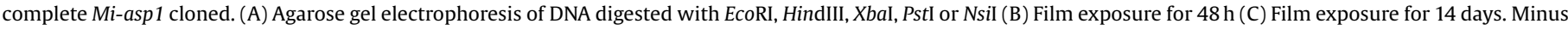
sign indicates restriction enzymes that do not cut the labeled region of Mi-asp1 gene. Scissors represent enzymes that cut the labeled region of $M i$-asp1 gene.

around 200 bp to the Mi-asp1 gene region flanked by NsiI restriction sites. Additionally, two very faint bands were noted after film overexposure probably related to other AP genes (Fig. 4C).

We performed RT-PCR amplification to analyze Mi-asp1 gene expression during $M$. incognita developmental life stages using specific primers for the $\beta$-actin and Mi-asp1 genes (Fig. 3). The negative control with no template did not amplify a fragment (Fig. 5), indicat-

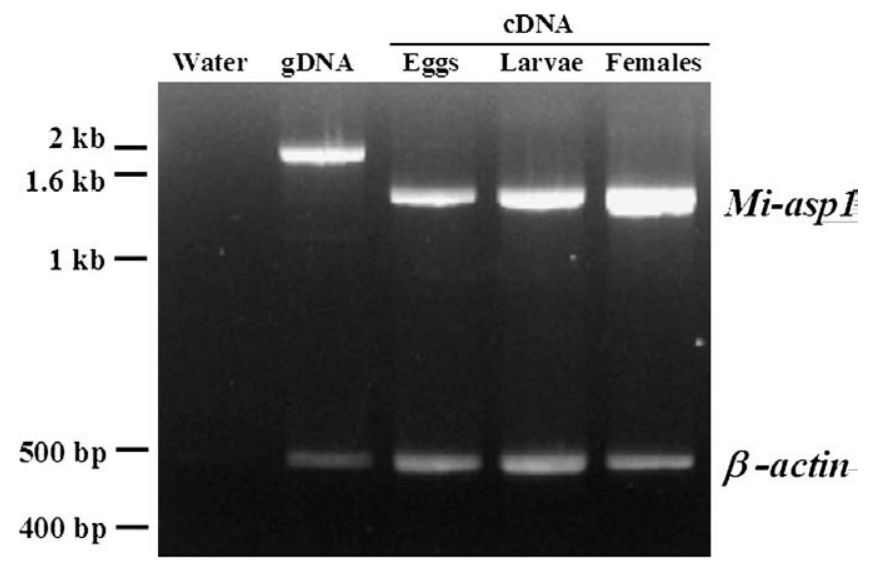

Fig. 5. Single microtube RT-PCR assays for Mi-asp1 gene expression. Water and genomic DNA controls validated the RT-PCR analysis. The cDNAs from eggs, L2 larvae and females of Meloidogyne incognita were used as templates for simultaneous amplification of Miasp1and $\beta$-actin. ing the absence of DNA contamination in the PCR reagents. When genomic DNA was used as a template, a fragment of the Mi-asp1 gene between 1.6 and $2 \mathrm{~kb}$ in length was amplified (Fig. 5). When using cDNAs from eggs, L2 with larvae and females as templates, fragments of the expected size of $1.3 \mathrm{~kb}$, corresponding to the Mi-asp1 cDNA, were amplified in all tested life stages (Fig. 5). This observed difference in amplicons suggests that intron(s) might be present within the Mi-asp1 gene. No fragment larger than $1.3 \mathrm{~kb}$ corresponding to the Mi-asp1 gene was detected by RT-PCR amplification, supporting the absence of gDNA contamination in the cDNA aliquots. The singletube reactions did co-amplify the $\beta$-actin fragments used for gene expression normalization. This RT-PCR analysis was conducted in three biological replicates. Several technical replicates showed similar Mi-asp1 amplification levels in M. incognita eggs and L2 larvae, but the level was higher in adult females (Fig. 5).

\subsection{Mining of ESTs encoding aspartic proteinase from Meloidogyne spp.}

Aiming to generate a global view of AP diversification and expression pattern, we performed a search in the RKN EST data banks and found 28 ESTs coding for APs (Table 2). Five ESTs encoding APs were found in RKN eggs, two for Meloidogyne paranaensis, and one each for Meloidogyne chitwoodi, Meloidogyne javanica, and Meloidogyne arenaria. Twenty AP ESTs were identified in RKN L2, four for $M$. incognita, seven for Meloidogyne hapla and nine for $M$. arenaria. Three AP ESTs were detected in RKN females, one for $M$. hapla and two for M. incognita. 
Table 2

Analysis of clusters of root-knot nematode ESTs encoding APs from the GenBank ${ }^{\mathrm{TM}}$.

\begin{tabular}{|c|c|c|c|c|}
\hline EST clusters $^{\mathrm{a}}$ & RKN species & Life stages & $\begin{array}{l}\text { GenBank }^{\mathrm{TM}} \\
\text { accession }\end{array}$ & BLASTx results $^{\mathrm{b}}$ \\
\hline A1.1 pepsin-like & M. arenaria & L2 & $\begin{array}{l}\text { CF357960 } \\
\\
\text { CF357948 } \\
\text { CF357852 } \\
\text { CF357235 } \\
\text { CF357186 }\end{array}$ & $\begin{array}{l}\text { AAD09345 Strongyloi- } \\
\text { des stercoralis (3e-05) } \\
26 \%\end{array}$ \\
\hline A1.2 Pepsin-like & M. arenaria & $\mathrm{L} 2$ & $\begin{array}{l}\text { CF358275 } \\
\text { CF357624 } \\
\text { CF357084 }\end{array}$ & $\begin{array}{l}\text { AAD09345 S. sterco- } \\
\text { ralis (5e-09) } 29 \%\end{array}$ \\
\hline A2 pepsin-like & M. hapla & L2 & $\begin{array}{l}\text { CA997489 } \\
\text { BU094921 } \\
\text { BU094650 } \\
\text { BQ836667 }\end{array}$ & $\begin{array}{l}\text { AAB65878 C. elegans } \\
(4 \mathrm{e}-07) 29 \%\end{array}$ \\
\hline $\begin{array}{l}\text { B cathepsin } \\
\text { D-like }\end{array}$ & $\begin{array}{l}\text { M. javanica } \\
\text { M. arenaria } \\
\text { M. arenaria } \\
\text { M. incognita }\end{array}$ & $\begin{array}{l}\text { Egg } \\
\text { Egg } \\
\text { L2 } \\
\text { L2 }\end{array}$ & $\begin{array}{l}\text { BE578940 } \\
\text { BI746532 } \\
\text { CF358292 } \\
\text { AW829206 } \\
\text { AW870930 } \\
\text { AW871162 } \\
\text { AW783012 } \\
\text { CF980496 } \\
\text { CF802901 }\end{array}$ & Mi-asp1 (1e-119) 97\% \\
\hline $\begin{array}{l}\text { C cathepsin } \\
\text { D-like }\end{array}$ & M. paranaensis & Egg & $\begin{array}{l}\text { CK242497 } \\
\text { CK242452 }\end{array}$ & $\begin{array}{l}\text { AAX33731 Blomia } \\
\text { tropicalis (2e-89) 76\% }\end{array}$ \\
\hline D pepsin-like & M. hapla & L2 & CN572742 & $\begin{array}{l}\text { CAA08899 C. elegans } \\
(4 \mathrm{e}-08) 30 \%\end{array}$ \\
\hline E pepsin-like & M. hapla & $\mathrm{L} 2$ & BU094593 & $\begin{array}{l}\text { BAA19607 Cucurbita } \\
\text { pepo (3e-07) } 28 \%\end{array}$ \\
\hline $\begin{array}{l}\text { F cathepsin } \\
\text { D-like }\end{array}$ & M. hapla & Female & CN576295 & Mi-asp1 (6e-24) 61\% \\
\hline $\begin{array}{l}\text { G cathepsin } \\
\text { D-like }\end{array}$ & M. hapla & $\mathrm{L} 2$ & BQ836960 & Mi-asp1 (4e-11) 80\% \\
\hline $\begin{array}{l}\text { H cathepsin } \\
\text { D-like }\end{array}$ & M. chitwoodi & Egg & CB931365 & $\begin{array}{l}\text { CAE65791 C. briggsae } \\
(3 e-26) 56 \%\end{array}$ \\
\hline
\end{tabular}

a The cluster name and the nematode AP class.

${ }^{\mathrm{b}}$ In parenthesis, the $E$-value, followed by percentage of peptide sequence identity.

These AP ESTs were assembled in 10 clusters of different AP genes and/or non-overlapping regions of the same gene (Table 2). The consensus sequences of clusters were compared to the database for BLASTx searches and were classified as cathepsin D-like AP or pepsin-like AP, which are the two groups of nematode APs.

Clusters A1.1 and A1.2 encode different proteins, but are closely related, corresponding to pepsin-like APs. The four ESTs of cluster A2 encode an N-terminal protein similar to pepsin-like AP. Cluster $\mathrm{D}$ corresponds to the $\mathrm{C}$-terminal end of pepsin-like AP, without overlapping regions with cluster A2 because of a predicted 111-bp region between them. Cluster $\mathrm{E}$, despite the high similarity to plant APs, probably encodes a homolog of pepsin-like AP.

Cluster C, formed by two identical ESTs, matches with arthropod APs and Mi-asp1 ( $E$-value of 7e-55, and identity of $66 \%$ ). This sequence does not encode $\mathrm{Mi}$-asp1, but rather a closely related homolog with $80 \%$ similarity over an alignment of 155 amino acids. Cluster $\mathrm{H}$, with only one EST, presents the BLASTx alignment with cathepsin D-like APs of Caenorhabditis briggsae and C. elegans ( $E$-value of $7 \mathrm{e}-25$ and identity of $53 \%$ ). Cluster $\mathrm{C}$ and $\mathrm{H}$ align with the N-terminus of the cathepsin D-like APs.
Cluster B corresponds to cathepsin D-like APs in C. elegans (E-value of $1 \mathrm{e}-64$ and identity of $65 \%$ ) and encodes $50 \%$ of the $\mathrm{N}$-terminus of Mi-asp1, as reported here. Cluster $\mathrm{G}$, comprising just one sequence, encodes the C-terminus of Mi-asp1, and therefore does not match cluster B. This EST does not appear identical to Mi-asp1 probably because of sequencing errors, since all differences were in just one, short region. Cluster F seems related to $\mathrm{Mi}$-asp1, despite a relatively low identity percentage (E-value of $6 e-24$ and identity of $61 \%$ ). Its only EST contains one region that matches with Mi-asp1 and another region with adenosine bias and nucleotide repetition, a characteristic indication of problematic sequencing.

\subsection{Characterization of the deduced amino acid sequence of Mi-asp1}

The Mi-asp1 encodes a pro-region of 71 amino acid residues and a mature proteinase of 378 amino acid residues (Fig. 3 ), with a predicted molecular mass of $41.502 \mathrm{kDa}$ and a theoretical $\mathrm{pI}$ of 5.27. Domain analysis of Mi-asp1 by using the CDD-Search (Conserved Domain Database) showed an $E$-value of $7 \mathrm{e}-105$ with a conserved domain of eukaryotic aspartyl proteinase (pfam00026.12). An analysis using the Conserved Domain Architecture Retrieval Tool (CDART) indicated that Mi-asp1 possesses a single AP domain structure. The BLASTp analysis of Mi-asp1 showed high sequence identity with eight proteins (Table 3 ) grouped in the subfamily of nematode cathepsin D-like APs (Williamson et al., 2003b). Such sequences were aligned with Mi-asp1 for further comparisons and function prediction (Fig. 6). These nematode APs also share putative sites for disulfide bridges and $\mathrm{N}$-glycosylation sites positioned as found in vertebrate non-lysosomal cathepsin $\mathrm{E}$ (Fig. 6 ). On the other hand, some paralog nematode APs (pepsinogenlike) appeared to be distantly related to this group of cathepsin D APs.

Since the amplified sequence is incomplete at the N-terminus, analysis with SignalP software did not identify any preregion for Mi-asp1. However, after submitting to SignalP, the 40 best matches with Mi-asp1 from BLASTp hits and then aligning them all without their signal peptides (data not shown), we could predict the putative cleavage site at residues 5-6 (VSS-IR) of the Mi-asp1 sequence. In fact, the two ESTs from M. incognita females belonging to Cluster B (CF980496 and CF802901) encode the N-terminal region (MSKLSLIAIFSLF), which is absent in the cloned Mi-asp1 fragment, though perfectly contiguous with a region covering $50 \%$ of the Mi-asp 1 sequence. The putative zymogen activation site that divides the pro-region from the mature proteinase was predicted through sequence comparisons with several nematode APs (Fig. 6). Mi-asp1 shares several features with the recently defined group of nematode cathepsin D-like APs (Fig. 6), with one $N$-glycosylation site, four disulfide bridges and conserved motifs around the two catalytic aspartic residues (Fig. 3).

\section{Discussion}

Several strategies based on proteolytic inhibitors of proteinases, pro-regions of cognate proteinases, specific antibodies or RNA interference have been tested to inhibit and disrupt proteinase activity of plant-parasitic nematodes. In an attempt to engineer plant resistance against endoparasitic nematodes, we looked for potential targets. In this context, we have performed the present studies focused on the aspartic proteinase (AP) in the root-knot nematode (RKN) M. incognita.

Crude protein extracts of $M$. incognita females demonstrated AP activity when using AP-specific substrates and inhibitors (Table 1), motivating AP gene cloning efforts. Indeed, three cDNAs encoding AP were identified by RT-PCR amplification of $M$. incognita second- 
Table 3

Characterization of aspartic proteinases belonging to the subfamily nematode-specific cathepsin D-like proteins (A01.068 or nemepsin-2, by MEROPS).

\begin{tabular}{|c|c|c|c|c|c|c|c|}
\hline \multirow[t]{2}{*}{ Nematode (lifestyle) } & \multirow[t]{2}{*}{ Sequence names } & \multirow{2}{*}{$\begin{array}{l}\text { Accession } \\
\text { numbers }\end{array}$} & \multirow[t]{2}{*}{ Identity/E-value } & \multicolumn{2}{|l|}{ Localization } & \multirow{2}{*}{$\begin{array}{l}\text { Developmental stage and/ } \\
\text {-or function }\end{array}$} & \multirow[t]{2}{*}{ References } \\
\hline & & & & Subcellular & Histological & & \\
\hline $\begin{array}{l}\text { Caenorhabditis briggsae } \\
\text { (free-living nematode) }\end{array}$ & $\begin{array}{l}\text { Hypothetical pro- } \\
\text { tein }\end{array}$ & CAE61399 & $64.073 \%, 1.2 \mathrm{e}-128$ & - & - & - & Unpublished \\
\hline $\begin{array}{l}\text { Necator americanus } \\
\text { (animal parasite) }\end{array}$ & $\begin{array}{l}\text { Na-APR-1 necep- } \\
\text { sin II }\end{array}$ & CAC00543 & $65.144 \%, 3.4 \mathrm{e}-128$ & - & $\begin{array}{l}\text { Intestine, amphids and } \\
\text { excretory/secretory } \\
\text { glands }\end{array}$ & $\begin{array}{l}\text { L3 and adult Hemoglobin, } \\
\text { serum and skin proteins } \\
\text { digestion }\end{array}$ & $\begin{array}{l}\text { Williamson et al. } \\
\text { (2002) }\end{array}$ \\
\hline $\begin{array}{l}\text { Caenorhabditis elegans } \\
\text { (free-living nematode) }\end{array}$ & asp-4 R12H7.2 & NP_510191 & $64.524 \%, 8.9 e-128$ & $\begin{array}{l}\text { Cytoplasm and } \\
\text { lysosome }\end{array}$ & $\begin{array}{l}\text { Intestine, hypodermis, } \\
\text { muscle and neurons }\end{array}$ & $\begin{array}{l}\text { Late embryogenesis and } \\
\text { early L1 Neurodegene- } \\
\text { ration }\end{array}$ & $\begin{array}{l}\text { Syntichaki et al. } \\
(2002)\end{array}$ \\
\hline $\begin{array}{l}\text { Ancylostoma ceylanicum } \\
\text { (animal parasite) }\end{array}$ & $A y-A P R-1$ AceyASP & AAO22152 & $63.593 \%, 9.6 e-127$ & - & - & - & Unpublished \\
\hline $\begin{array}{l}\text { Brugia malayi (animal } \\
\text { parasite) }\end{array}$ & BmAsp-2 & BAC05689 & $62.061 \%, 6.6 \mathrm{e}-121$ & - & - & - & Unpublished \\
\hline $\begin{array}{l}\text { Ancylostoma caninum } \\
\text { (animal parasite) }\end{array}$ & Ac-APR-1 Acasp1 & AAB06575 & $59.859 \%, 4.9 \mathrm{e}-116$ & - & $\begin{array}{l}\text { Intestine, amphids and } \\
\text { excretory/secretory glands }\end{array}$ & $\begin{array}{l}\text { L3 and adult Hemoglobin, } \\
\text { serum and skin proteins } \\
\text { digestion }\end{array}$ & $\begin{array}{l}\text { Williamson et al. } \\
(2002)\end{array}$ \\
\hline $\begin{array}{l}\text { Onchocerca volvulus } \\
\text { (animal parasite) }\end{array}$ & $O v-A P R$ & AAD00524 & $59.950 \%, 1.2 \mathrm{e}-110$ & Lysosome & $\begin{array}{l}\text { Intestine, hypodermis, and } \\
\text { reproductive organs }\end{array}$ & $\begin{array}{l}\text { Mature oocytes, early } \\
\text { morulae and adult. Diges- } \\
\text { tion, oogenesis, embryo- } \\
\text { genesis and degeneration }\end{array}$ & $\begin{array}{l}\text { Jolodar et al. } \\
(2004)\end{array}$ \\
\hline $\begin{array}{l}\text { Heterodera glycines } \\
\text { (plant parasite) }\end{array}$ & Hgg-33 & AAL78216 & $71.282 \%, 3.4 \mathrm{e}-65$ & Lysosome & Intestine & - & Gao et al. (2001) \\
\hline
\end{tabular}

Identities and identities and E-values were measured by pairwise comparisons of overlapping-region between Mi-asp1 and each protein sequence.

stage (L2) larvae (Fig. 2). Using 5' RACE and 3' RACE strategies (Fig. 1 ) one of them was isolated and named Mi-asp1 (Accession No. DQ360827). The Mi-asp1 sequence encodes a putative AP zymogen presenting a classical pre-pro-protein format (Fig. 3). The pro-region and the mature proteinase of the Mi-asp1 sequence are complete, with 71 and 378 residues, respectively.

The amplification of three different cDNAs by RT-PCR (Fig. 2), the hybridization pattern obtained by Southern blot (Fig. 4), and the assembly of ESTs encoding APs (Table 2) collectively indicate the existence of an AP gene family in $M$. incognita with at least three members and that Mi-asp1 is probably a single-copy gene, like its orthologs (Tcherepanova et al., 2000; Jolodar et al., 2004) grouped in Table 3.

According to Merops' classification (http://www.merops.sanger.ac.uk/), nematode APs are grouped into two subfamilies belonging to the peptidase family $\mathrm{A} 1$ (i.e., pepsin family) of the Clan AA (i.e., aspartic proteinases). The first subfamily is nemepsin-3 (A01.053), of which the only found is C. elegans ASP-1. The second is nemepsin-2 (A01.068), which is represented by C. elegans ASP-4 and several nematode APs (Table 3) currently reported in the literature including cathepsin D-like APs. Several other nematode APs are only grouped as unassigned peptidases (A01.UPA), including C. elegans ASP-2, -3, -5, and -6. However, some of these unassigned peptidases present a unifying, common feature, which is a cysteine-rich insertion of 30-35 amino acids. Thus, there is clearly another well-characterized group, called pepsinogen-like APs (or nemepsins), which includes C. elegans ASP-2 (Geier et al., 1999; Tcherepanova et al., 2000), Haemonchus contortus HcPEP-1 (Longbottom et al., 1997) and HcPEP-2 (Smith et al., 2003), N. americanus Na-APR-2 or necepsin-I (Williamson et al., 2003c). Other unassigned peptidases have high sequence identity with each other, but lack the cysteine-rich insertion, such as C. elegans ASP-5 and 6, B. malayi BmAsp-1 and BmAsp-3, and Strongyloides stercoralis Strongyloidespepsin (Gallego et al., 1998).

The multiple sequence alignment of predicted Mi-asp1 and nematode cathepsin D-like APs demonstrate some specific aspects of this group (Fig. 6), including a long pro-region, a putative $N$-glycosylation site, putative cysteine bonds and a high degree of sequence identity and similarity to each other. Some
Mi-asp1 orthologs were studied in terms of functional characterization and cellular localization (Table 3). Nematode cathepsin D-like APs lack the conserved $N$-glycosylation site, which is known to be important in vertebrate cathepsin D targeting to the lysosome (Wittlin et al., 1999). Initially, they were believed to be non-lysosomal (Jolodar and Miller, 1997; Jolodar and Miller, 1998); however, it was later found that they do localize to lysosomes (Jolodar et al., 2004).

Some studies have shown that nematode AP expression is developmentally regulated (Table 3 ), and probably is the same in RKN. From the 28 ESTs encoding APs found in the data banks (Table 2), 14 sequences encode cathepsin D-like APs and 14 encode pepsinogen-like APs. This first group has sequences distributed in eggs (5 ESTs), L2 larvae (6 ESTs) and adult females (3 ESTs), suggesting gene expression during all life stages. In fact, we amplified a Mi-asp1 fragment using cDNA from eggs, L2 larvae and females (Fig. 5), suggesting that all life phases of $M$. incognita may be susceptible to cathepsin D-like AP inhibition. In contrast, the ESTs encoding pepsinogen-like APs were all found in L2 larvae in the infective phase. Despite the absence of expression analysis, these data remain suggestive. Some direct involvement of pepsinogen-like APs in RKN invasion and migration could be expected, such as $\beta$-1,4-endoglucanase, xylanase and pectate lyase (Caillaud et al., 2008), yet indirect roles could also be possible. The L2 is also a non-feeding stage (Wyss et al., 1992) that obtains energy through the consumption of its own lipid reserves (Reversat, 1981), probably through the glyoxylate pathway (McCarter et al., 2003).

Both cathepsin D-like and pepsinogen-like APs from animalparasitic nematodes have been strongly correlated with digestion of host hemoglobin, skin and/or other tissues (Brindley et al., 2001; Brinkworth et al., 2001; Morales et al., 2004; Williamson et al., 2003a). However, nematode APs are also involved in several other cellular processes, such as egg hatching and ecdysis (Masler et al., 2001), oogenesis (Jolodar et al., 2004), embryogenesis (Jolodar et al., 2004; Syntichaki et al., 2002), fat body histolysis (Rabossi et al., 2004), aging mechanisms and necrotic cell death related to neurodegeneration (Samara and Tavernarakis, 2003).

The importance of APs in plant-nematode interactions needs to be further evaluated. Therefore, inhibitory strategies targeting APs 


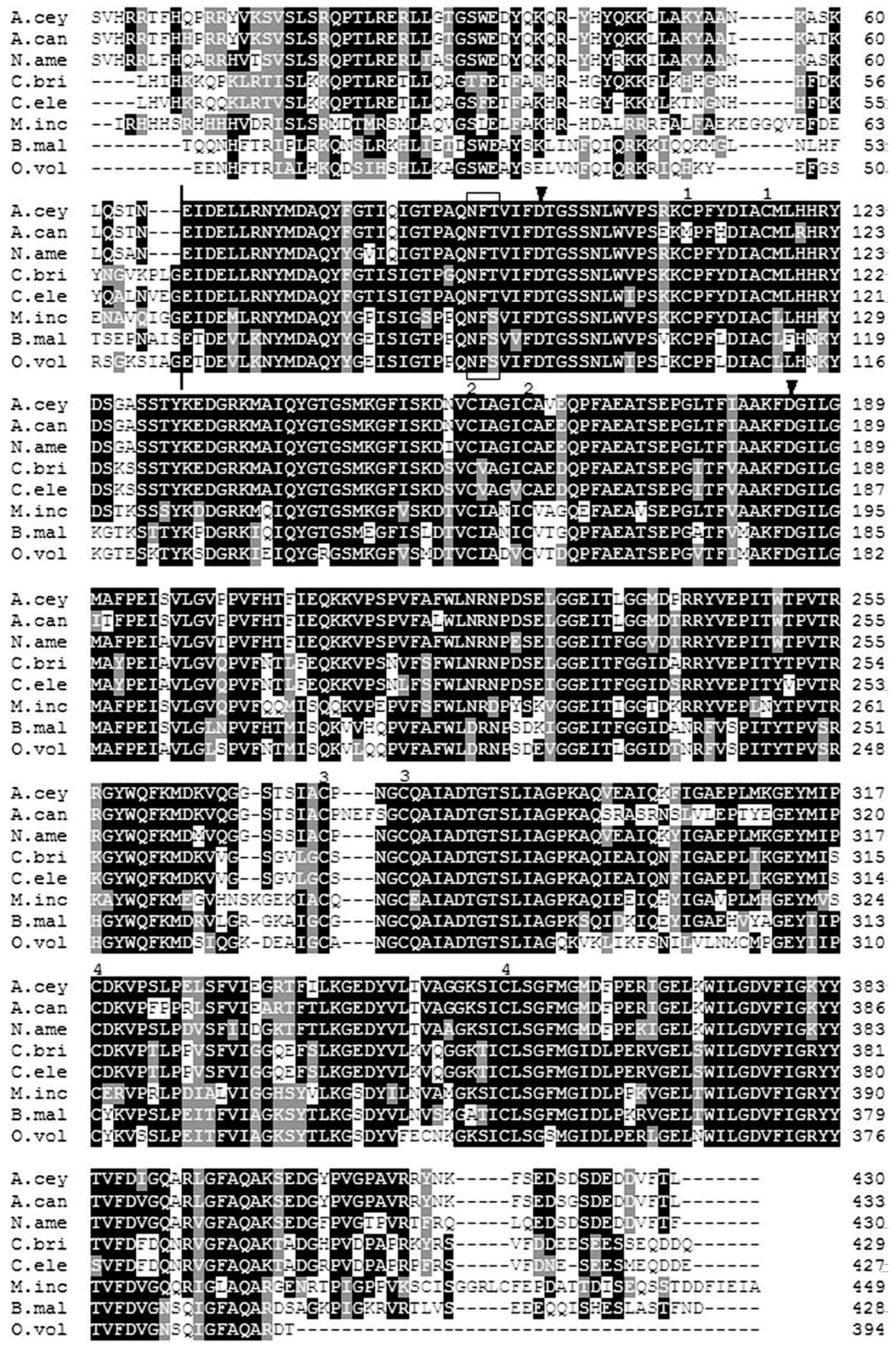

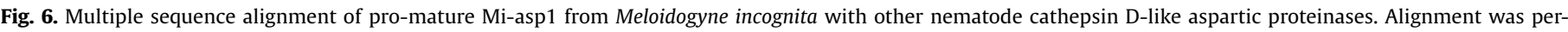

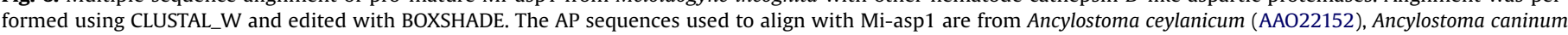

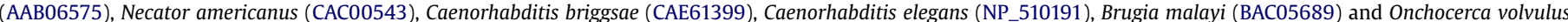

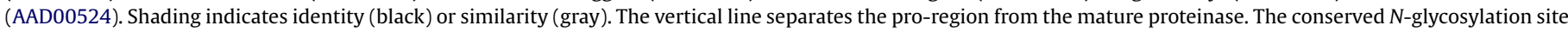

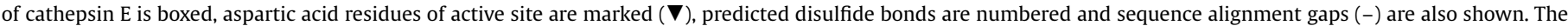
numbering does not consider the pre-region (signal peptide).

could be tested against all phases of RKN. Subsequent studies are still necessary to localize the tissue and subcellular expression of
Mi-asp1, to define its substrates, and to determine its role in plant parasitism or nematode physiology. 


\section{Acknowledgments}

This work was supported by grants from EMBRAPA, CNPq, and CAPES, Brazil.

\section{References}

Altschul, S.F., Gish, W., Miller, W., Myers, E.W., Lipman, D.J., 1990. Basic local alignment search tool. Journal of Molecular Biology 215, 403-410.

Atkinson, H.J., Green, J., Cowgill, S., Levesley, A., 2001. The case for genetically modified crops with a poverty focus. Trends in Biotechnology 19, 91-96.

Beynon, R.J., Bond, J.S., 1994. Proteolytic Enzymes: A Practical Approach. IRL Press, Oxford University PressMolecular.

Bird, D.M., Kaloshian, I., 2003. Are roots special? Nematodes have their say. Physiological and Molecular Plant Pathology 62, 115-123.

Brindley, P.J., Kalinna, B.H., Wong, J.Y., Bogitsh, B.J., King, L.T., Smyth, D.J., Verity, C.K., Abbenante, G., Brinkworth, R.I., Fairlie, D.P., Smythe, M.L., Milburn, P.J., Bielefeldt-Ohmann, H., Zheng, Y., McManus, D.P., 2001. Proteolysis of human hemoglobin by schistosome cathepsin D. Molecular and Biochemical Parasitology $112,103-112$

Brinkworth, R.I., Prociv, P., Loukas, A., Brindley, P.J., 2001. Hemoglobin-degrading, aspartic proteases of blood-feeding parasites: substrate specificity revealed by homology models. Journal of Biological Chemistry 276, 38844-38851.

Caillaud, M.C., Dubreuil, G., Quentin, M., Perfus-Barbeoch, L., Lecomte, P., de Almeida Engler, J., Abad, P., Rosso, M.N., Favery, B., 2008. Root-knot nematodes manipulate plant cell functions during a compatible interaction. Journal of Plant Physiology $165,104-113$.

Chitwood, D.J., 2003. Research on plant-parasitic nematode biology conducted by the United States Department of Agriculture-Agricultural Research Services. Pest Management Science 59, 748-753.

Coombs, G.H., Goldberg, D.E., Klemba, M., Berry, C., Kay, J., Mottram, J.C., 2001. Aspartic proteases of Plasmodium falciparum and other parasitic protozoa as drug targets. Trends in Parasitology 17, 532-537.

Davis, E.L., Hussey, R.S., Baum, T.J., 2004. Getting to the roots of parasitism by nematodes. Trends in Parasitology 20, 134-141.

Fragoso, R.R., Batista, J.A., Neto, O.B., Grossi de Sa, M.F., 2005. Isolation and characterization of a cDNA encoding a serine proteinase from the root-knot nematode Meloidogyne incognita. Experimental Parasitology 110, 123-133.

Gallego, S.G., Slade, R.W., Brindley, P.J., 1998. A cDNA encoding a pepsinogen-like, aspartic protease from the human roundworm parasite Strongyloides stercoralis. Acta Tropica 71, 17-26.

Gao, B., Allen, R., Maier, T., Davis, E.D., Baum, T.J., Hussey, R.S., 2001. Identification of putative parasitism genes expressed in the esophageal gland cells of the soybean cyst nematode Heterodera glycines. Molecular Plant-Microbe Interaction $14,1247-1254$.

Geier, G., Banaj, H.J., Heid, H., Bini, L., Pallini, V., Zwilling, R., 1999. Aspartyl proteases in Caenorhabditis elegans-Isolation, identification and characterization by a combined use of affinity chromatography, two-dimensional gel electrophoresis, microsequencing and databank analysis. European Journal of Biochemistry 264, 872-879.

Gheysen, G., Fenoll, C., 2002. Gene expression in nematode feeding sites. Annual Review of Phytopathology 40, 191-219.

Hussey, R.S., Barker, K.R., 1973. A comparison of methods of collecting inocula of Meloidogyne spp., including a new technique. Plant Disease Report 57, 10251028

Jean, L., Pery, P., Dunn, P., Bumstead, J., Billington, K., Ryan, R., Tomley, F., 2001. Genomic organisation and developmentally regulated expression of an apicomplexan aspartyl proteinase. Gene 262, 129-136.

Jolodar, A., Miller, D.J., 1997. Preliminary characterisation of an Onchocerca volvulus aspartic protease. International Journal for Parasitology 27, 1087-1090.

Jolodar, A., Miller, D.J., 1998. Identification of a novel family of non-lysosomal aspartic proteases in nematodes. Biochimica et Biophysica Acta 1382, 13-16.

Jolodar, A., Fischer, P., Buttner, D.W., Miller, D.J., Schmetz, C., Brattig, N.W., 2004. Onchocerca volvulus: expression and immunolocalization of a nematode cathepsin D-like lysosomal aspartic protease. Experimental Parasitology 107, $145-156$.

Kalkanci, A., Bozdayi, G., Biri, A., Kustimur, S., 2005. Distribution of secreted aspartyl proteinases using a polymerase chain reaction assay with SAP specific primers in Candida albicans isolates. Folia Microbiology (Praha) 50, 409-413.

Lilley, C.J., Devlin, P., Urwin, P.E., Atkinson, H.J., 1999a. Parasitic nematodes, proteinases and transgenic plants. Parasitology Today 15, 414-417.

Lilley, C.J., Urwin, P.E., Atkinson, H.J., 1999b. Characterization of plant nematode genes: identifying targets for a transgenic defence. Parasitology 118, S63-S72.

Lilley, C.J., Urwin, P.E., Atkinson, H.J., McPherson, M.J., 1997. Characterization of cDNAs encoding serine proteinases from the soybean cyst nematode Heterodera glycines. Molecular and Biochemical Parasitology 89, 195-207.

Lilley, C.J., Urwin, P.E., McPherson, M.J., Atkinson, H.J., 1996. Characterization of intestinally active proteinases of cyst-nematodes. Parasitology 113, 415-424.

Longbottom, D., Redmond, D.L., Russell, M., Liddell, S., Smith, W.D., Knox, D.P., 1997. Molecular cloning and characterization of a putative aspartate proteinase associated with a gut membrane protein complex from adult Haemonchus contortus. Molecular and Biochemical Parasitology 88, 63-72.

Marchler-Bauer, A., Anderson, J.B., DeWeese-Scott, C., Fedorova, N.D., Geer, L.Y., He, S., Hurwitz, D.I., Jackson, J.D., Jacobs, A.R., Lanczycki, C.J., Liebert, C.A., Liu,
C., Madej, T., Marchler, G.H., Mazumder, R., Nikolskaya, A.N., Panchenko, A.R., Rao, B.S., Shoemaker, B.A., Simonyan, V., Song, J.S., Thiessen, R.A., Vasudevan, S. Wang, Y., Yamashita, R.A., Yin, J.J., Bryant, S.H., 2003. CDD: a curated Entrez database of conserved domain alignments. Nucleic Acids Research 31, 383-387.

Masler, E.P., Kovaleva, E.S., Sardanelli, S., 2001. Aminopeptidase-like activities in Caenorhabditis elegans and the soybean cyst nematode, Heterodera glycines. Journal of Helminthology 75, 267-272.

McCarter, J.P., Mitreva, M.D., Martin, J., Dante, M., Wylie, T., Rao, U., Pape, D., Bowers, Y., Theising, B., Murphy, C.V., Kloek, A.P., Chiapelli, B.J., Clifton, S.W., Bird, D.M. Waterston, R.H., 2003. Analysis and functional classification of transcripts from the nematode Meloidogyne incognita. Genome Biology 4, R26.

Michaud, D., Cantin, L., Bonade-Bottino, M., Jouanin, L., Vrain, T.C., 1996. Identification of stable plant cystatin/nematode proteinase complexes using mildly denaturing gelatin/polyacrylamide gel electrophoresis. Electrophoresis 17 1373-1379.

Morales, M.E., Kalinna, B.H., Heyers, O., Mann, V.H., Schulmeister, A., Copeland, C.S., Loukas, A., Brindley, P.J., 2004. Genomic organization of the Schistosoma mansoni aspartic protease gene, a platyhelminth orthologue of mammalian lysosomal cathepsin D. Gene 338, 99-109.

Neveu, C., Abad, P., Castagnone-Sereno, P., 2003. Molecular cloning and characterization of an intestinal cathepsin L protease from the plant-parasitic nematode Meloidogyne incognita. Physiological and Molecular Plant Pathology 63, 159-165.

Nielsen, H., Engelbrecht, J., Brunak, S., von Heijne, G., 1997. Identification of prokaryotic and eukaryotic signal peptides and prediction of their cleavage sites. Protein Engineering 10, 1-6.

Rabossi, A., Stoka, V., Puizdar, V., Turk, V., Quesada-Allue, L.A., 2004. Novel aspartyl proteinase associated to fat body histolysis during Ceratitis capitata early metamorphosis. Archives of Insect Biochemistry and Physiology 57, 51-67.

Reversat, G., 1981. Consumption of food reserves by starved second-stage juveniles of Meloidogyne javanica under conditions including osmobiosis. Nematologica 27, 207-214.

Samara, C., Tavernarakis, N., 2003. Calcium-dependent and aspartyl proteases in neurodegeneration and ageing in C. elegans. Ageing Research Reviews 2, 451471.

Sambrook, J., Fritsch, E.F., Maniatis, T., 1989. Molecular Cloning. A Laboratory Manual, second ed. Cold Spring Harbor Laboratory Press, New York.

Silva, F.B., Batista, J.A., Marra, B.M., Fragoso, R.R., Monteiro, A.C., Figueira, E.L., Grossi-de-Sa, M.F., 2004. Pro domain peptide of HGCP-Iv cysteine proteinase inhibits nematode cysteine proteinases. Genetics and Molecular Research 3, 342-355.

Smith, W.D., Skuce, P.J., Newlands, G.F., Smith, S.K., Pettit, D., 2003. Aspartyl proteases from the intestinal brush border of Haemonchus contortus as protective antigens for sheep. Parasite Immunology 25, 521-530.

Syntichaki, P., Xu, K., Driscoll, M., Tavernarakis, N., 2002. Specific aspartyl and calpain proteases are required for neurodegeneration in C. elegans. Nature 419 939-944.

Tcherepanova, I., Bhattacharyya, L., Rubin, C.S., Freedman, J.H., 2000. Aspartic proteases from the nematode Caenorhabditis elegans. Structural organization and developmental and cell-specific expression of asp-1. Journal of Biological Chemistry 275, 26359-26369.

Thompson, J.D., Higgins, D.G., Gibson, T.J., 1994. CLUSTAL W: improving the sensitivity of progressive multiple sequence alignment through sequence weighting, position-specific gap penalties and weight matrix choice. Nucleic Acids Research 22, 4673-4680.

Trudgill, D.L., Blok, V.C., 2001. Apomictic, polyphagous root-knot nematodes: exceptionally successful and damaging biotrophic root pathogens. Annual Review of Phytopathology 39, 53-77.

Urwin, P.E., Lilley, C.J., Atkinson, H.J., 2002. Ingestion of double-stranded RNA by preparasitic juvenile cyst nematodes leads to RNA interference. Molecular Plant Microbe Interaction 15, 747-752.

Urwin, P.E., Lilley, C.J., McPherson, M.J., Atkinson, H.J., 1997a. Characterization of two cDNAs encoding cysteine proteinases from the soybean cyst nematode Heterodera glycines. Parasitology 114, 605-613.

Urwin, P.E., Lilley, C.J., McPherson, M.J., Atkinson, H.J., 1997b. Resistance to both cyst and root-knot nematodes conferred by transgenic Arabidopsis expressing a modified plant cystatin. Plant Journal 12, 455-461.

Urwin, P.E., McPherson, M.J., Atkinson, H.J., 1998. Enhanced transgenic plant resistance to nematodes by dual proteinase inhibitor constructs. Planta 204, 472-479.

Williamson, A.L., Brindley, P.J., Abbenante, G., Prociv, P., Berry, C., Girdwood, K. Pritchard, D.I., Fairlie, D.P., Hotez, P.J., Dalton, J.P., Loukas, A., 2002. Cleavage of hemoglobin by hookworm cathepsin $\mathrm{D}$ aspartic proteases and its potential contribution to host specificity. FASEB Journal 16, 1458-1460.

Williamson, A.L., Brindley, P.J., Knox, D.P., Hotez, P.J., Loukas, A., 2003a. Digestive proteases of blood-feeding nematodes. Trends in Parasitology 19, 417-423.

Williamson, A.L., Brindley, P.J., Loukas, A., 2003b. Hookworm cathepsin D aspartic proteases: contributing roles in the host-specific degradation of serum proteins and skin macromolecules. Parasitology 126, 179-185.

Williamson, A.L., Brindley, P.J., Abbenante, G., Datu, B.J., Prociv, P., Berry, C., Girdwood, K., Pritchard, D.I., Fairlie, D.P., Hotez, P.J., Zhan, B., Loukas, A., 2003c. Hookworm aspartic protease, Na-APR-2, cleaves human hemoglobin and serum proteins in a host-specific fashion. Journal of Infectious Diseases 187, 484-494.

Wittlin, S., Rosel, J., Hofmann, F., Stover, D.R., 1999. Mechanisms and kinetics of procathepsin D activation. European Journal of Biochemistry 265, 384-393.

Wyss, U., Grundler, F.M.W., Munch, A., 1992. The parasitic behaviour of secondstage juveniles of Meloidogyne incognita in roots of Arabidopsis thaliana. Nematologica 38, 98-111. 